UDC 621

\title{
Knock Reduction Measures in the Gas Fuelled Internal Combustion Engine
}

\author{
S. Szwaja ${ }^{1)}$ \\ ${ }^{1)}$ Czestochowa University of Technology (Czestochowa, Republic of Poland) \\ (C) Белорусский национальный технический университет, 2020 \\ Belarusian National Technical University, 2020
}

\begin{abstract}
Studies on the influence of applying various technologies for combustion knock reduction have been presented in the paper. Among others, investigation concerning the following: over-expanded cycle, variable valve timing, internal and exhaust gas recirculation, leaning the combustible mixture and cooling the in-cylinder charge were of the interest. The research works were focused on impact of these technologies on both knock intensity reduction, and engine performance and toxic emissions. Results presented in the paper were coming from experimental investigation based on in-cylinder combustion pressure data acquisition. Additionally, knock intensity calculation methods were discussed. They are based on in-cylinder combustion pressure pulsations. Combustion knock intensity expressed by the maximum peak of the incylinder pressure pulsations shows a strong negative correlation with both the EGR ratio and relative equivalence ratio lambda. With respect to a catalytic converter installed on the exhaust pipe line, applying EGR appears as better solution for knock reduction then leaning the combustible mixture because the catalytic converter needs stoichiometric mixture for effective $\mathrm{NO}_{x}$ reduction. Furthermore, application of the over-expanded cycle to the hydrogen or coke gas fueled IC engine significantly reduces intensity of potential knock by $50 \%$ in comparison to Otto cycle for all loads. Additionally, over-expanded cycle contributes to increase in engine thermal efficiency. Summing up, all the presented measures and technologies can be successfully implemented into practice in stationary engines as well as in traction engines, both of them working on either natural gas or gaseous renewable fuels.
\end{abstract}

Keywords: combustion, knock, heat release rate, hydrogen

For citation: Szwaja S. (2020) Knock Reduction Measures in the Gas Fuelled Internal Combustion Engine. Science and Technique. 19 (4), 339-348. https://doi.org/10.21122/2227-1031-2020-19-4-339-348

\section{Меры по уменьшению стука в газовом двигателе внутреннего сгорания С. Швайя ${ }^{1)}$ \\ 1)Ченстоховский технологический университет (Ченстохова, Республика Польша)}

Реферат. В статье изучается влияние различных технологий на уменьшение детонации при сгорании. Среди рассматриваемых вопросов следует упомянуть следующие: сверхрасширенный цикл, регулируемые фазы газораспределения, внутренняя рециркуляция и рециркуляция отработанных газов, обеднение горючей смеси и охлаждение заряда в цилиндре. Исследования направлены на изучение влияния используемых технологий на снижение интенсивности детонации, вредных выбросов и работу двигателя. Результаты испытаний получены в ходе экспериментальных исследований, основанных на сборе данных о давлении сгорания в цилиндрах. Кроме того, изучались методы расчета интенсивности детонации. Эти методы основаны на пульсациях давления сгорания в цилиндрах. Интенсивность детонации сгорания, выраженная максимальным пиком пульсаций давления в цилиндре, показывает отрицательную корреляцию с отношением как рециркуляции отработанных газов, так и с отношением относительной эквивалентности - лямбда. Что касается каталитического нейтрализатора, установленного на линии выхлопной трубы, применение рециркуляции отработанных газов представляется лучшим решением для уменьшения детонации с последующим обеднением горючей смеси, поскольку каталитическому нейтрализатору требуется стехиометрическая смесь для эффективного подавления окислов азота. При этом применение чрезмерно расширенного цикла к двигателю внутреннего сгорания, работающему на водороде или коксовом газе, снижает интенсивность потенциальной детонации на $50 \%$ по сравнению с циклом Отто при всех нагрузках. Кроме всего прочего, чрезмерно расширенный цикл способствует увеличению теплового коэффициента полезного действия двигателя. Обобщая результаты исследований, можно сказать, что все предложенные меры и технологии могут быть успешно реализованы на практике в стационарных двигателях, а также в тяговых двигателях, работающих на природном газе или газообразном возобновляемом топливе.

Ключевые слова: горение, стук, скорость выделения теплоты, водород

Для цитирования: Швайя, С. Меры по уменьшению стука в газовом двигателе внутреннего сгорания / С. Швайя // Наука и техника. 2020. Т. 19, № 4. С. 339-348. https://doi.org/10.21122/2227-1031-2020-19-4-339-348

\author{
Адрес для переписки \\ Швайя Станислав \\ Ченстоховский технологический университет \\ ул. Дабровскего, 69, \\ 42-201, г. Ченстохова, Республика Польша \\ Тел.: +48 343 250-524 \\ szwaja@imc.pcz.czest.pl
}

\author{
Address for correspondence \\ Szwaja Stanislaw \\ Czestochowa University of Technology \\ 69, Dabrowskiego str., \\ 42-201, Czestochowa, Republic of Poland \\ Tel.: +48 343 250-524 \\ szwaja@imc.pcz.czest.pl
}


Strong environment protection regulations on carbon dioxide emission from vehicles force scientists to work on several liquid and gaseous substances which can substitute fossil fuels. Thus, investigation is concentrated on applying hydrogen or biomass based fuels as alcohols, bio-oils and methane rich gases for this purpose. It was found that alternative fuels can be burnt in both spark ignition and compression ignition engines as it was discussed in. However, burning gaseous renewable fuels in compression ignition engines needs a pilot diesel fuel for combustion initiation. On the other hand, the spark ignited engine features with knock effect occurring at unfavorable operating conditions, particularly in case hydrogen is applied as a fuel. As far as knock comes from auto-ignition of premixed combustible mixture, such phenomena might also be observed in a dual-fuel compression ignition engine fueled with premixed gaseous fuels.

Among other things, combustion knock is one of the most important constraints, which significantly reduces both the performance, torque output and efficiency of the spark ignited (SI) internal combustion (IC) engine. On the other hand, hydrogen as a gaseous fuel for the IC engine, gives it a significant advantage over other commonly used fuels including gasoline, diesel, and ethanol [1]. Thus, mixture of hydrogen and natural gas can be considered as valuable fuel to the SI engine. $20 \% \mathrm{H}_{2}$ in natural gas mixture is known as hythane and was successfully implemented in test buses. These advantages include potential of near zero emissions of the regulated emissions of carbon monoxide $(\mathrm{CO})$, nitric oxides $\left(\mathrm{NO}_{x}\right)$, and hydrocarbons (HC) while simultaneously eliminating carbon dioxide $\left(\mathrm{CO}_{2}\right)$ emissions, and greatly improved cold start capability. Hydrogen's combustion properties enable the development of an engine that would meet all current and future emissions standards. It is reported $[1,2]$ that hydrogen as engine fuel has great potential for improving engine thermal efficiency due to its rapid combustion, which approaches the ideal constant-volume heat release combustion process.

Combustion knock results from the spontaneous ignition of the end gas mixture inside the engine cylinder ahead of the propagating flame [3]. When this abnormal combustion occurs, there is a rapid release of the chemical energy in the remaining unburned mixture, causing high local pressures and generating propagating pressure waves in amplitude of several hundred $(\mathrm{kPa})$ across the cylinder space. These pressure waves are transmitted through the engine body and results in the combustion ping heard by observers. The large amplitude pressure waves of the hot combusted gases in the cylinder are the primary reason for mechanical engine failure through increased thermal and mechanical stress (Fig. 1). The pressure waves that result from combustion knock occur at frequencies that are acoustic vibration modes of the cylinder geometry. Hence, intensity of combustion knock can be easily calculated on the basis of high frequency oscillations on pressure inside the engine cylinder during combustion. The amplitude of these oscillations can be as high as peak of combustion pressure, so they could increase the incylinder pressure twice [4-6]. This combustion causes faster wear of the engine, thus from this point of view is considered as unwelcome combustion phenomenon.

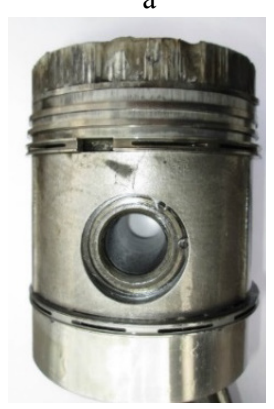

$\mathrm{b}$

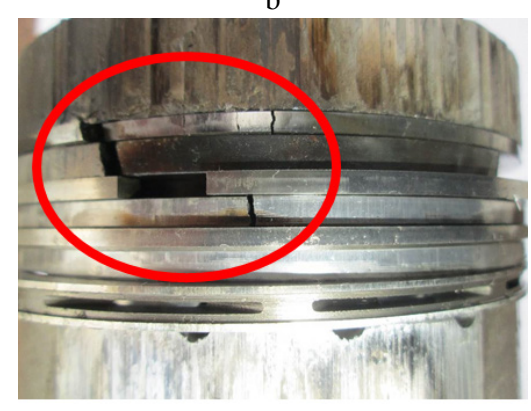

Fig. 1. Piston damaged by the severe knock (a) details on piston rings (b)

Detection of combustion knock is the necessary measure in the modern engine control system to prevent the engine from working with abnormal combustion as combustion knock is. The detection is usually realized by a vibration sensor installed on the engine body. There is almost linear correlation between knock intensity and engine body vibration, thus such monitoring of combustion knock can be easily conducted. Although, running the engine under knock is undesirable due to shortening the engine durability, but working just at the edge of combustion knock can provide favorable conditions for maximum engine performance. It is particularly observed when bad quality fuels are applied. The knock detecting system provides real-time monitoring of the engine and in case of 
the knock the control system retards spark timing to eliminate this improper combustion. The best for the engine is to work without the knocking. Thus, prediction of potential combustion knock is the main target of research in the field. It particularly stimulates development in knowledge of knock genesis, knock precursors, fuel properties, cylinder design, etc. Theory and modeling the combustion knock can be valuable tools for computational simulation of engine working cycles and their analysis. Although, several, experimentally determined, correlations between knock intensity and quantities as pre-ignition temperature and ignition lag are satisfactory recognized, but origin of this phenomenon still needs to be theoretically examined in details. Thus, it makes the sub-model of combustion knock more universal and provides opportunity of knock prediction in various engine types as well as experimental models do it for specified engines with limits in working conditions.

Combustion knock occurring in the IC spark ignited engine is a phenomenon, which is sensitive to several quantities. They can influence on knock intensity at various impacts. Several quantities are identified and their impact on the knock is moreless recognized. They can be distinguished as follows:

- temperature of pre-ignition gases - it has significant impact on an induction time (pre-ignition reactions) and strongly impacts on combustion knock $[1,4]$. Compression ratio is one of the parameters influencing on the pre-ignition temperature;

- $\mathrm{O}-\mathrm{H}$ (oxygen to hydrogen) ratio, which might be expressed by the lambda - relative equivalence ratio, which is a factor showing hydrogen active radicals dilution in fresh combustible mixture;

- oxygen dilution in the intake charge - provided by exhaust gas recirculation (EGR);

- presence of hot spots, exhaust residuals they can work as extra sources for uncontrolled airfuel ignition;

- initial swirls, intake manifold shape, combustion chamber shape;

- engine load - fuel dose - higher engine load requires higher amounts of fuel delivered to the engine cylinder, hence it provides energy released during combustion and also influences the knock intensity.
Majority of these above mentioned quantities are not independent from each other, for example fuel dose and lambda, that could change the knock. As known through literature survey $[1,2,7,8]$, research on knock reduction in the SI engine by diluting air-fuel combustible mixture is rich of credible results. It is confirmed, that engines working on air-gas lean mixtures are more resistant to knock [7]. Similar impact is observed, while applying EGR. It contributes to remarkable reduction in knock intensity [8]. These both measures can be used to reduce knock intensity in stationary gas fueled engines for heat and power generation. The paper presents measures to effectively reduce combustion knock intensity even to completely eliminate it. Therefore, there are two major effective methods to reduce combustion knock in the engine. Knock can be reduced by either applying EGR or fueling the engine with lean air-fuel mixture. Investigation presented concerns impact of both these measures on reducing combustion knock intensity in the SI reciprocating engine fueled with hydrogen rich gases. Investigation involves hydrogen and natural gas as fuels to the IC engine. Hydrogen addition to methane contributes to increase in laminar flame speed (LFS) of this combustible mixture, that shortens entire combustion duration in the engine cylinder and finally leads to higher engine overall efficiency. Natural gas with a calorific value of $9.7 \mathrm{~kW} \cdot \mathrm{h} / \mathrm{nm}^{3}$ constitutes a high-value fuel for effective power generation.

\section{Knock intensity determination}

As mentioned, knock intensity is determined on the basis of pressure pulsation intensity. Fig. 2 and 3 presents combustion pressure and high-pass filtered pressure pulsations for hydrogen combustion in the SI engine under two various compression ratios (CR) of 10 and 12 . As observed, pressure pulsations from Fig. $3(\mathrm{CR}=12)$ are several times higher than these from Fig. $2(\mathrm{CR}=10)$. Hydrogen as a fuel was not selected by coincidence. It is observed, that pressure pulsations start immediately after combustion development. They are not formed at the end combustion phase as is typical for gasoline knock. As seen in Fig. 4 combustion knock by end-gas self-ignition is accompanied with high MFB (Mass Fraction fuel Burnt) rate. 


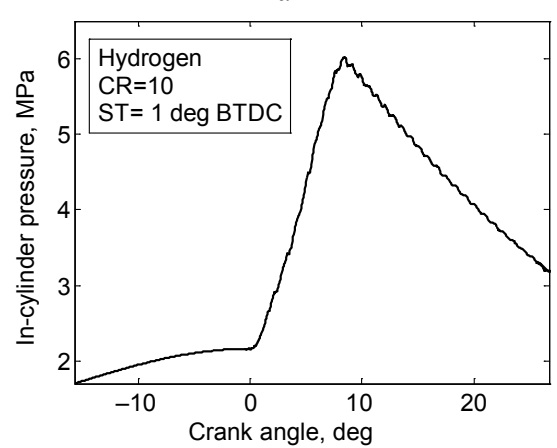

b

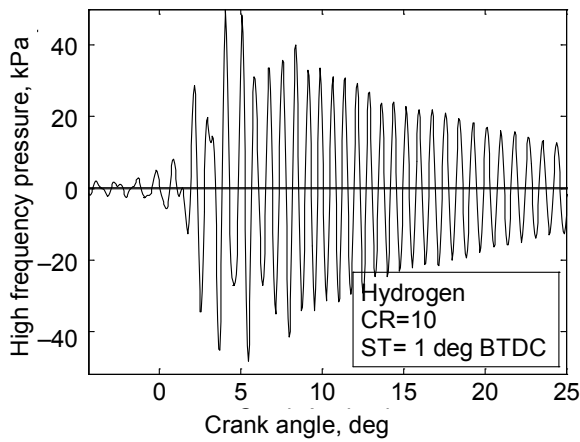

Fig. 2. Plots for engine work cycle at light knock for $\mathrm{CR}=10$ : $\mathrm{a}$ - in-cylinder combustion pressure; $\mathrm{b}$ - high frequency pressure of the combustion pressure

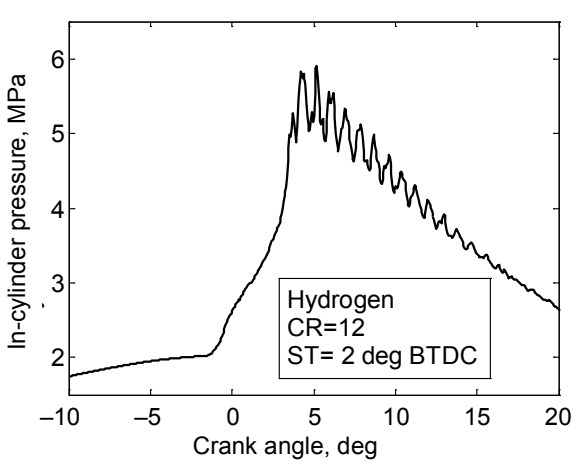

b

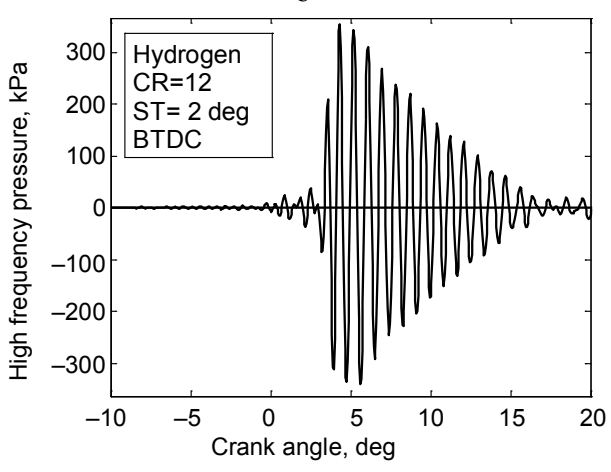

Fig. 3. Plots for engine work cycle at light knock for $\mathrm{CR}=10$ : $\mathrm{a}, \mathrm{b}-$ also as in Fig. 2

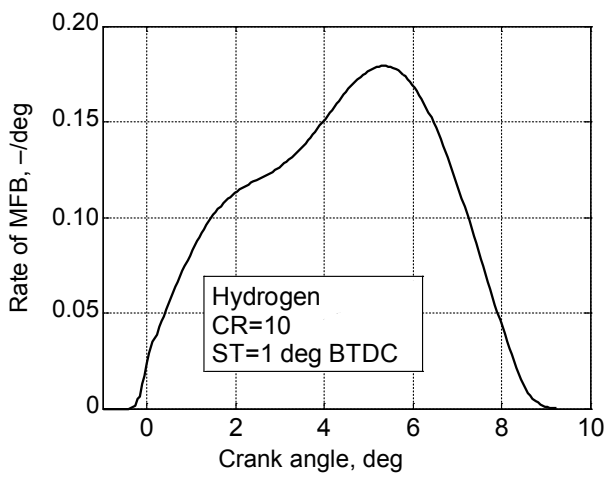

$\mathrm{b}$

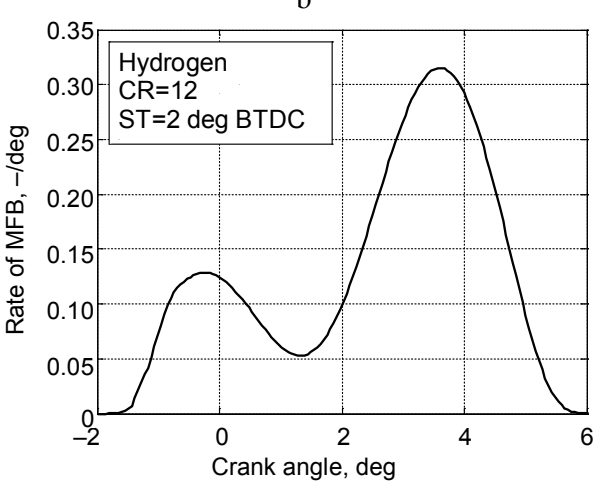

Fig. 4. Rate of MFB for the engine with $\mathrm{CR}=10$ (a) and $\mathrm{CR}=12$ (b)

Knock metrics. There are several metrics for in-cylinder pressure pulsations. Here the peak pressure $(P P)$ is proposed as the credible metrics which are easy to be determined. Thus, $P P$ metrics from an individual combustion event as defined as follows

$$
P P_{i}=\max \left[\left|\operatorname{HFPO}_{i}(t)\right|\right]
$$

And $P P$ for test series can be calculated

$$
P P=\frac{1}{n} \sum_{i=1}^{i=n} P P_{i},
$$

where $P P_{i}$ - peak pressure $(P P)$ of the $\mathrm{HFPO}_{i}$ taken from the single combustion event (Fig. 5a); $P P$ - mean of the $P P_{i}$ (test series usually contains 120 combustion events) (Fig. 5b). 


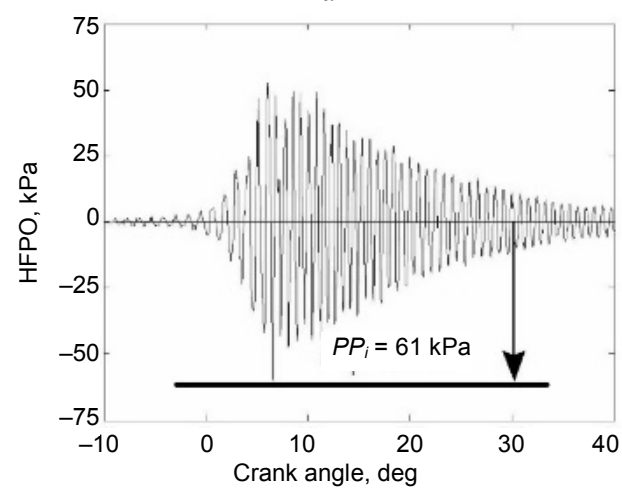

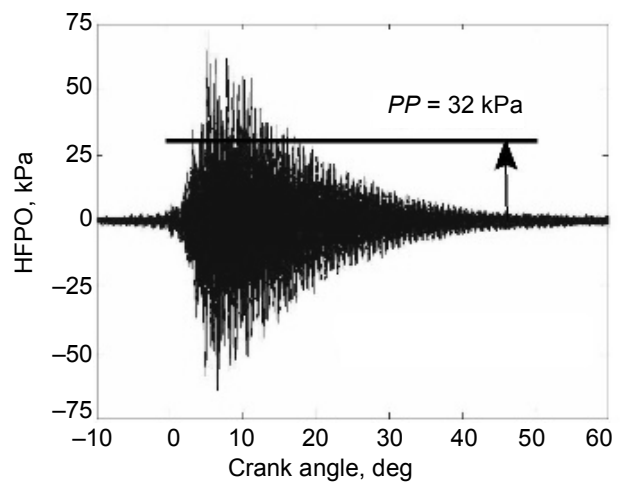

Fig. 5. Graphical interpretation of the $P P_{i}$ for a single combustion event (a), the $P P$ for a test series consisted of 300 consecutive combustion events (b)

Based on the $P P$ metrics correlation between knock intensity and compression ratio was determined for the hydrogen SI fuelled engine (Fig. 6). As seen, combustion knock to specific limit features with so-called combustion instabilities, which come from unstable combustion. Typical knock as end gas self-ignition defined by Heywood for the gasoline fueled engine starts with its intensity several times higher, as seen for $\mathrm{CR}$ over 12 in Fig. 6 [9].

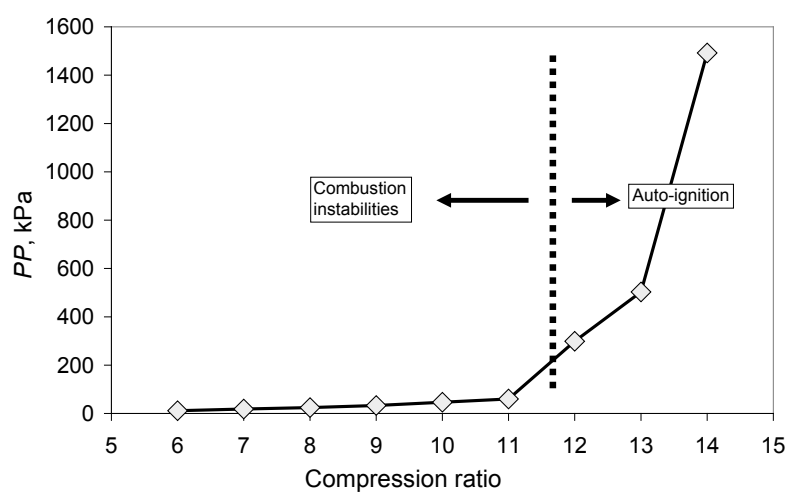

Fig. 6. The averaged intensity $P P$ vs compression ratio for the hydrogen fueled engine and pressure oscillations corresponding to specific compression ratios.

Tests were conducted with hydrogen-air stoichiometric mixtures at $\mathrm{ST}=0 \mathrm{deg}$

\section{In-cylinder exhaust residuals impact}

In-cylinder exhaust gases residuals (ExR) influence on engine in-cylinder combustion progress as diluent. However, exhaust residuals can differ from external EGR with temperature and moisture content. As known, diluent simply lengthens combustion duration, so reduces combustion knock intensity. In this case, higher exhaust residuals might lead to opposite correlation due to increase in temperature of fresh charge by higher ExR content $[10,11]$.

Experimental set-up. The tests were conducted on the single cylinder research engine based on Ricardo's Hydra platform. The engine specifications are provided in Tab. 1 [10].

Table 1

Specifications of the single cylinder Hydra engine [10]

\begin{tabular}{|c|c|}
\hline Parameter & Description \\
\hline Base engine & GM Ecotec GEN II LAF \\
\hline Bore & $86.00 \mathrm{~mm}$ \\
\hline Stroke & $94.60 \mathrm{~mm}$ \\
\hline Connecting rod length & $152.5 \mathrm{~mm}$ \\
\hline Wrist pin offset & $0.8 \mathrm{~mm}$ \\
\hline Displacement & $0.55 \mathrm{dm}^{3}$ \\
\hline Compression Ratio & 10.93:1 \\
\hline PFI injection & Methane \\
\hline Cam Phasing & Dual independent high authority \\
\hline Engine Control & $\begin{array}{l}\text { Prototype for full set-point } \\
\text { operation of throttle, fuel, } \\
\text { spark, cams, etc. }\end{array}$ \\
\hline
\end{tabular}

The engine setup is shown in Fig. 7a. Variable valve overlap was achieved through phasing the intake valve timing relative to a fixed exhaust valve timing. The intake valve cam center line location (ICCL) varies from 90 to 150 crank angle (CA) deg after TDC (top dead center), while the exhaust valve cam centerline location (ECCL) was fixed at $95 \mathrm{CA}$ deg before TDC. The valve profiles are shown in Fig. 7b. Detailed test specifications are provided in Tab. 2. 
Specifications of the tests

\begin{tabular}{|c|l|c|c|}
\hline No & \multicolumn{1}{|c|}{ Parameter } & Test 1 & Test 2 \\
\hline 1 & Engine speed & $\begin{array}{c}1250 \mathrm{rpm} \\
2000 \mathrm{rpm}\end{array}$ \\
\hline 2 & $\begin{array}{l}\text { Relative air to fuel ratio "lambda" } \\
\text { combustible mixture }\end{array}$ & $1.01 \ldots 1.04$ \\
\hline 3 & Fixed load NMEP & $(450 \pm 7) \mathrm{kPa}$ & $(450 \pm 7) \mathrm{kPa}$ \\
\hline 4 & $\begin{array}{l}\text { Fixed location for 50 \% fuel burnt CA50, to } \\
\text { obtain MBT, which is the highest for CA50 of } \\
7^{\circ}-10^{\circ} \mathrm{CA} \text { after TDC }\end{array}$ & $7.2^{\circ} \pm 0.5^{\circ} \mathrm{CA}$ & $8.1^{\circ} \pm 0.5^{\circ} \mathrm{CA}$ \\
\hline 5 & Data Acquisition & 300 consecutive combustion cycles per test \\
\hline 6 & Exhaust emission & The emission were logged for $60 \mathrm{~s}$ at sample rate of $1 \mathrm{~Hz}$ \\
\hline
\end{tabular}

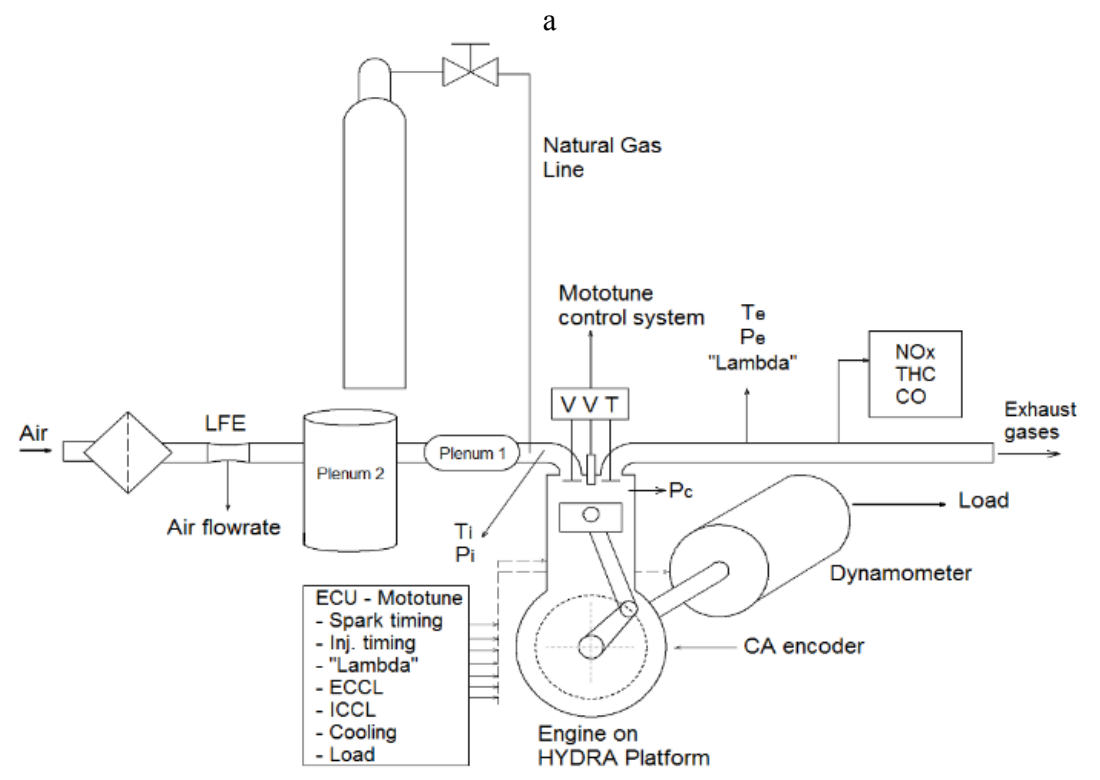

b

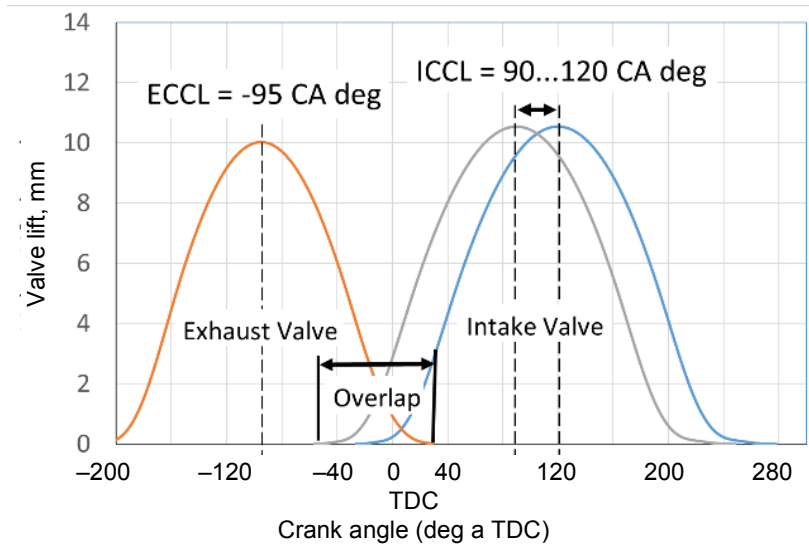

Fig. 7. Hydra engine setup (a), intake and exhaust valve lift profiles (b)

Results and discussion. As observed in Fig. 8 ExR plots are in line with engine overlap. Moreover, higher engine rotational speed $(2000 \mathrm{rpm})$ forces higher exhaust residuals percentage ratio.
Results presented in Fig. 9 confirm that higher ExR contributes to shorter combustion duration, both for these two specific phases: CA0-10 and CA10-90. Hence, temperature impact from higher 
ExR on combustion duration is more significant rather than its dilution.

As expected, shorter combustion duration is strictly correlated with higher heat release rate (HRR) as depicted in Fig. 10.

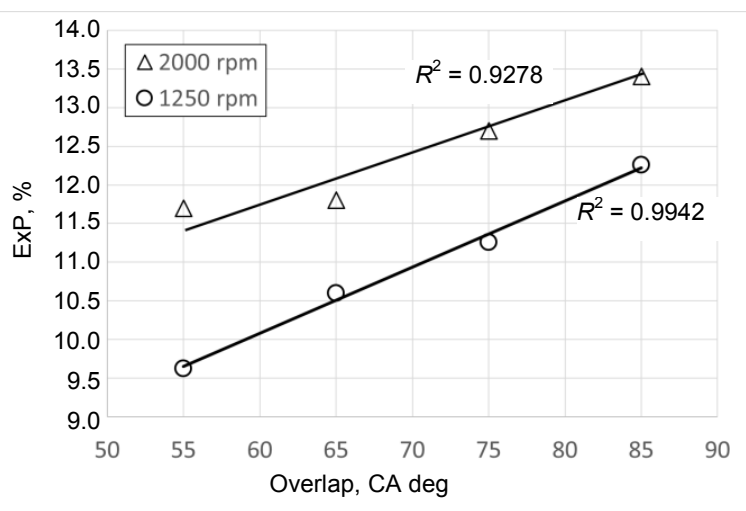

Fig. 8. Correlation between overlap and exhaust residuals (ExR)

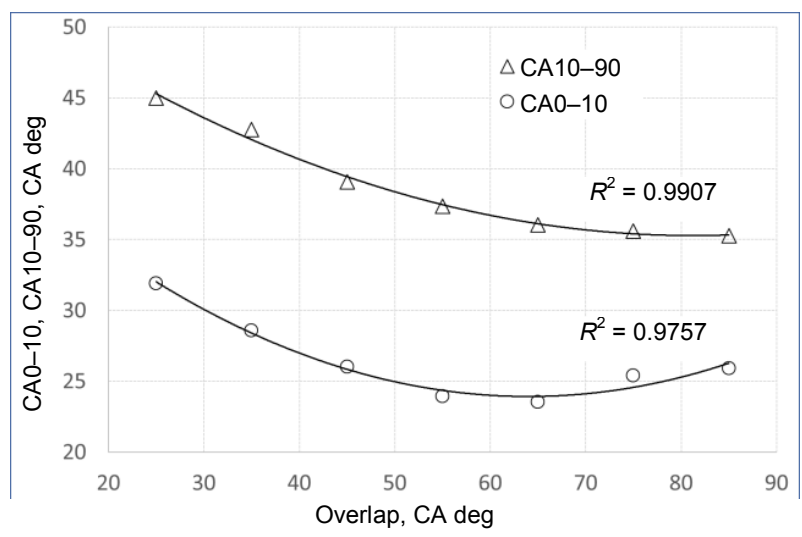

Fig. 9. CA0-10 and CA10-90 combustion phases vs overlap

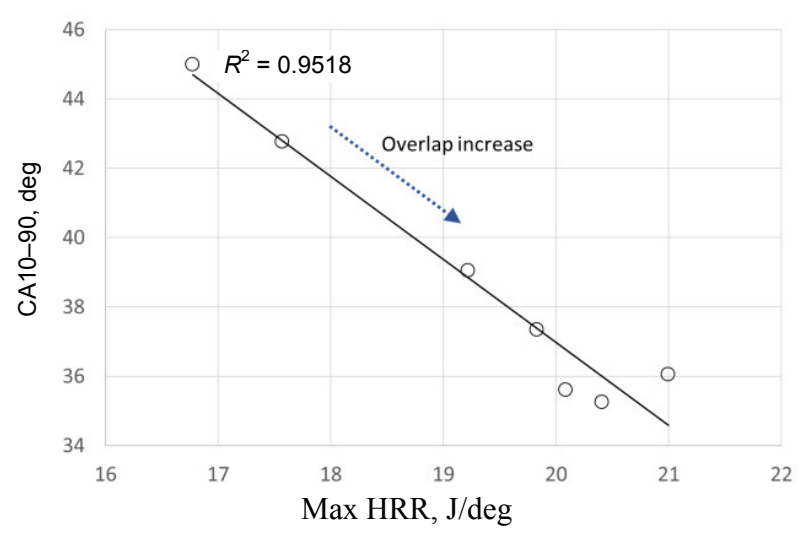

Fig. 10. CA10-90 vs HRR

Knock intensity expressed by metrics $P P$ goes down with higher overlap, as is seen in Fig. 11. The correlation is strongly exponential, hence one can conclude that it is influenced by chemical reac- tion rate that is affected by both temperature and exhaust residuals content in the fresh charge.

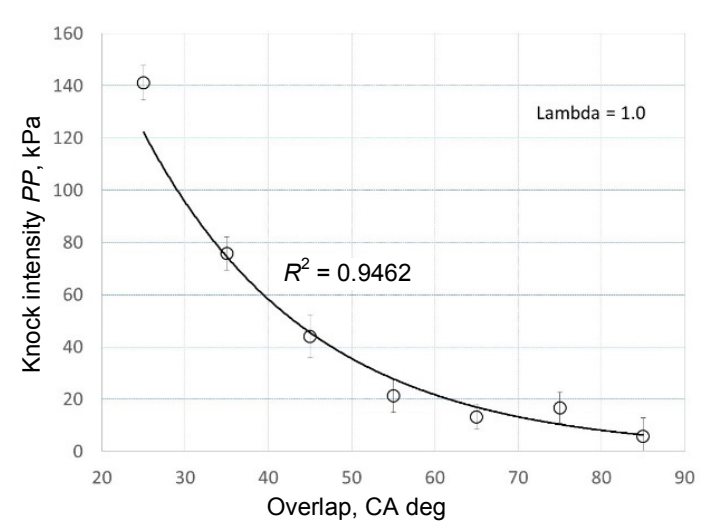

Fig. 11. Knock intensity $P P$ vs overlap

\section{External exhaust gases impact}

As mentioned, diluent can reduce knock intensity. Exhaust gases consisted of two major species $\mathrm{CO}_{2}$ and $\mathrm{H}_{2} \mathrm{O}$ can play crucial role in diluting combustible mixture without changing its equivalence ratio (relative equivalence ratio $\lambda$ ). As observed in Fig. 12a, $\mathrm{b}$ both higher percentage of EGR and higher ratio of leaning the combustible mixture leads to increase combustion duration $[7,8]$.

Target of the research works was to answer which measure (EGR or lean mixture) for air-fuel mixture dilution with respect to reducing combustion knock is more effective. To solve this problem, the dilution ratio $\chi$ was introduced follow the equation

$$
\chi=\frac{n_{s t}}{n_{s t}+n_{d i l}} \cdot 100 \%,
$$

where $\chi$-dilution ratio in percentage; $n_{s t}$ - number of moles (including fuel and oxidizer) of the stoichiometric air-gas mixture; $n_{d i l}-$ number of moles of additional gas working as a diluent.

This dilution ratio $\chi$, expressed as diluent mole percentage, makes it possible to compare knock reduction by EGR with knock reduction by lean mixture.

Dilution ratio defined with the equation (3) depends on lambda - relative air-fuel equivalence ratio in case the diluent is air. Hence, following the equation (3) a lean combustible mixture can be treated as the stoichiometric mixture diluted in extra amounts of air. If EGR is applied for diluting the mixture, then the dilution ratio $\chi_{d i l}$ is a function of the EGR ratio. 

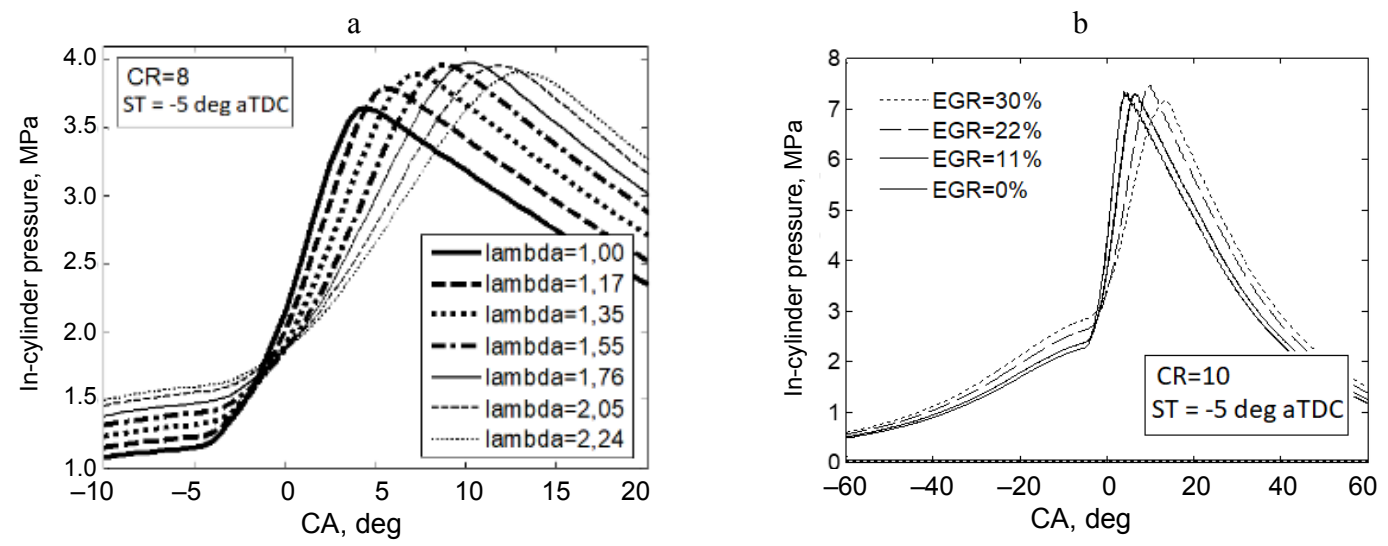

Fig. 12. In-cylinder pressure traces for various lambdas (a) and for various several EGR levels (b) during hydrogen combustion in the CFR engine

In case of applying the EGR as diluent, then the dilution ratio can be expressed as follows:

$$
\chi_{\mathrm{EGR}}=\frac{n_{s t}}{n_{s t}+n_{\mathrm{EGR}}} \cdot 100 \%,
$$

where $n_{s t}$ - number of moles of exhaust gases recirculating to the engine intake port.

Number of moles $n_{i}$ of each gas can be easily calculated

$$
n_{i}=\frac{m_{i}}{M W_{i}}
$$

where $m_{i}$ - mass of the $i$ agent; $M W_{i}-$ molar weight of the $i$ agent.

Finally, comparison between EGR and leaning impacts were able to be performed. As depicted in Fig. 13, EGR can be considered as more effective measure to reduce combustion knock rather than leaning the combustible mixture. It can be explained by $\mathrm{CO}_{2}$ and $\mathrm{H}_{2} \mathrm{O}$ presence in the exhaust gases. Unlike additional dilution by $\mathrm{O}_{2}$ in leaning, both $\mathrm{CO}_{2}$ and $\mathrm{H}_{2} \mathrm{O}$ are hardly active in combustion process.

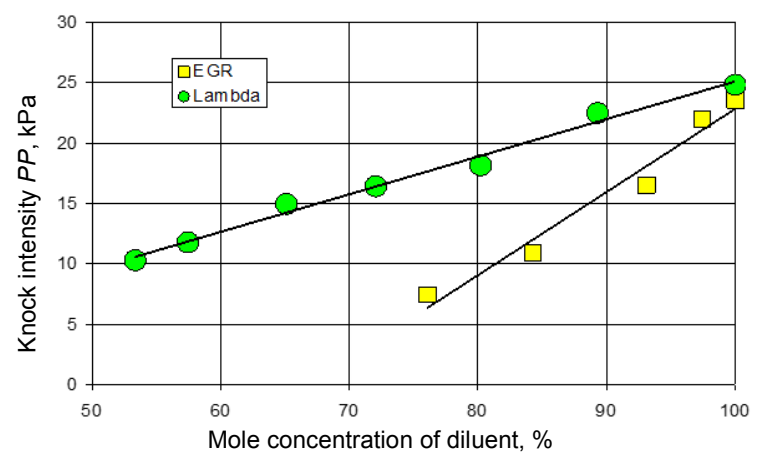

Fig. 13. Knock intensity for EGR and leaning the combustible mixture - comparison vs mole percentage - fuel: hydrogen at $\mathrm{ST}=-5 \mathrm{deg}$ aTDC

\section{Impact of over-expanded cycle on knock intensity}

Investigation in applying over-expanded cycle for both knock and exhaust toxic emissions reduction were described in detail in the works [12-15]. The test bed in the research consists of a singlecylinder spark ignited supercharged engine. The Kistler sensor type 6055 with the Kistler signal charge amplifier type 5011 were used in-cylinder pressure measurements. Pressure in intake manifold was measured by the Motorola MPX 4250 pressure sensor. TDC position and crankshaft positions were measured by the Megatron type MOB 1024/5/BZ/N encoder with resolution of 1024 pulses per revolution. Data measured during the tests were collected with aid of National Instruments data acquisition system NI USB-6251 which was connected to the PC were the data were stored. The over-expanded cycle was achieved by modification of the intake valve timing. In this case the intake valve closure point was located before bottom dead center during intake stroke. It is known as Miller cycle. The test rig specification is presented in Tab. 3 .

All measurements were done at wide open throttle conditions in two stages. In the first stage the optimal spark timing was determined for three boost overpressure, in the second stage to find optimal spark timing, the load of the engine was changed by changing a boost overpressure from 0 to 0.6 bar. The excess air ratio $\lambda$ was maintained constant during the tests and it was close to stoichiometric mixture expressed by $\lambda=1$.

Test matrix is presented in Tab. 4 . The optimal ignition timing was determined for three loads of 
the engine which were set by changing the boost overpressure. In each set point of the load the ignition timing was changed from 40 to 20 degree bTDC (before top dead center).

Table 3

Test rig specification

\begin{tabular}{|l|l|}
\hline \multicolumn{1}{|c|}{ Parameter } & \multicolumn{1}{|c|}{ Value } \\
\hline \multirow{2}{*}{ Type } & $\begin{array}{l}4-\text { stroke, water cooled, spark } \\
\text { ignited }\end{array}$ \\
\hline Number of cylinders & $1-$ horizontal \\
\hline CR & $11: 1$ \\
\hline Rotational speed, rpm & 1270 \\
\hline Bore, mm & 102 \\
\hline Stroke, mm & 120 \\
\hline Displacement, ccm & 980 \\
\hline \multirow{2}{*}{ Intake valve opening angle } & $11^{\circ}$ after TDC \\
\cline { 2 - 2 } & $11^{\circ}$ after TDC (Miller) \\
\hline Intake valve closure angle & $30^{\circ}$ after BDC \\
\cline { 2 - 2 } & $20^{\circ}$ before BDC (Miller) \\
\hline $\begin{array}{l}\text { Exhaust valve opening } \\
\text { angle }\end{array}$ & $30^{\circ}$ after BDC \\
\hline $\begin{array}{l}\text { Exhaust valve closure } \\
\text { angle }\end{array}$ & $0^{\circ}$ in TDC \\
\hline \multicolumn{2}{|c|}{ Dynometer } \\
\hline Synchronous generator, V & $3 \times 230$ \\
\hline Power, kVA & 20 \\
\hline \multicolumn{2}{|c|}{ Supercharger } \\
\hline Type & EATON M65 \\
\hline Boost pressure, bar & $0 \div 1.9$ \\
\hline
\end{tabular}

Table 4

Test matrix

\begin{tabular}{|c|c|c|c|}
\hline Fuel & $\begin{array}{c}\text { Ignition timing, } \\
\text { deg bTDC }\end{array}$ & $\lambda(-)$ & $p_{\text {boost }}$, bar \\
\hline $\begin{array}{c}\text { Methane } \\
\text { (stage I) }\end{array}$ & $\begin{array}{c}\text { Variable from } \\
40 \text { to } 20\end{array}$ & $1.05 \pm 0.05$ & $0.0 ; 0.3 ; 0.6$ \\
\hline $\begin{array}{c}\text { Methane } \\
\text { (stage II) }\end{array}$ & Optimal 29 & $1.05 \pm 0.05$ & $0.0 \div 0.6$ \\
\hline
\end{tabular}

Body temperature of the engine was maintained at $70{ }^{\circ} \mathrm{C}$ and the temperature of the fresh air after supercharger was maintained at $24{ }^{\circ} \mathrm{C}$. Methane was delivered to the engine by a gas mixer which was installed in the intake manifold. The air/fuel ratio was set according to the measurements of air and fuel flows by rotor flow meters.

On the basis of these data the pressure-volume, pressure-time and engine load vs spark timing plots were made. These data allowed to perform analysis on combustion process and knock occurrence. Fig. 14 presents knock intensity $P P$ vs boosting pressure for the engine working with clas- sic Otto cycle and the engine with over-expanded cycle $(\mathrm{O}-\mathrm{E})$. As one can notice knock is significantly reduced by applying over-expanded Miller cycle to the engine. It is obviously known that knock is also in strict inline correlation with engine load. As presented in Fig. 15, knock intensity increases with increase in engine load for Otto cycle engine unlike the over-expanded cycle engine, where intensity of knock slightly goes down even the engine load increases.

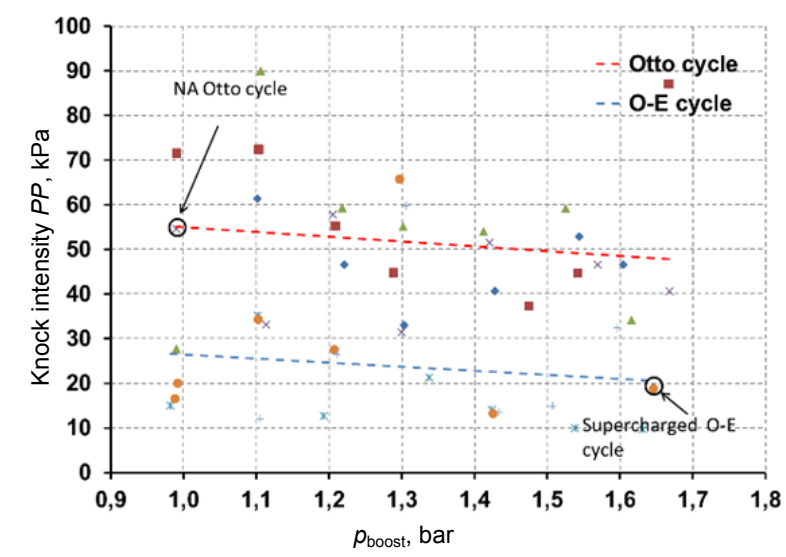

Fig. 14. Knock intensity for Otto and over-expanded Miller cycles vs boosting pressure

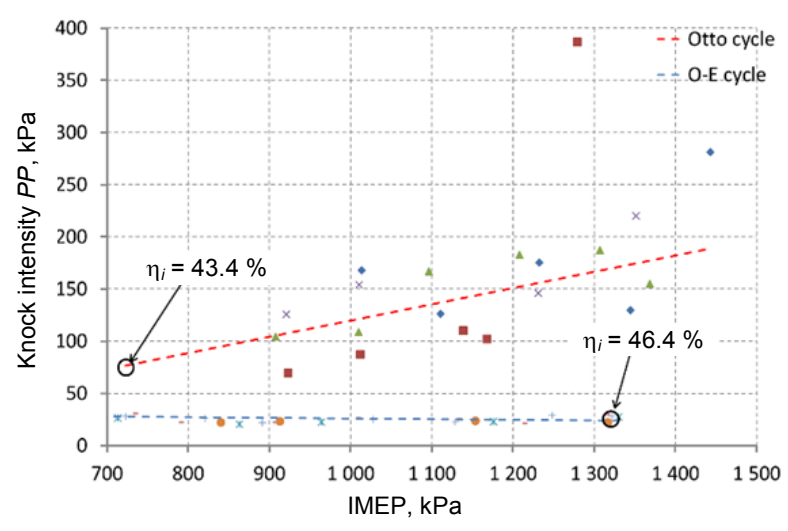

Fig. 15. Knock intensity for Otto and over-expanded Miller cycles vs engine load (IMEP)

The results of the research confirm benefits which come from applying the over-expanded cycle to the supercharged SI IC engine. On the basis of the research the following conclusions can be drawn: the optimal ignition timing does not depend on engine cycle type - classic Otto or overexpanded. Moreover, the optimal value is the same for the Otto cycle and the over-expanded cycle engine. In both versions of the engine, increase in boost pressure does not affect on optimal ignition timing, in all cases ignition timing was $28^{\circ}$ before TDC. 


\section{CONCLUSIONS}

1. High frequency in-cylinder pressure pulsations, generated by improper combustion processes causing knocking, decrease when EGR ratio increases for the conditions examined.

2. Combustion knock intensity expressed by the maximum peak of the in-cylinder pressure pulsations shows a strong negative correlation with the EGR ratio for stoichiometric hydrogen combustion under the conditions examined:

- higher hydrogen dose makes combustion knock more intensive under the same lambda. Then intensified knock significantly shortens combustion duration even if a mass of hydrogen is higher;

- combustion knock intensity decreases when $\mathrm{H}_{2}$ air mixture becomes leaner. The dependence between lambda and knock intensity $P P$ is nearly linear;

- with respect to a catalytic converter installed on the exhaust pipe line, applying EGR appears as better solution for knock reduction then leaning the combustible mixture because the catalytic converter needs stoichiometric mixture for effective $\mathrm{NO}_{x}$ reduction.

3. It can be observed, that for both the naturally aspirated and the boosted engine with boost overpressure of 0.3 bar a peak combustion pressure is lower for the engine with over-expanded cycle if compared to this one with Otto cycle. For maximum boost pressure of 0.6 bar the peak in combustion pressure is not changed.

4. Application of the over-expanded cycle to the IC engine reduces intensity of potential knock what can be observed. Reduction in pressure pulsations of combustion pressure for over-expanded cycle engine in comparison to Otto cycle engine is approximately $50 \%$ for all loads.

5. Over-expanded cycle contributes to increase in engine thermal efficiency. As determined, this increase was approximately $1.2 \%$ from $40.3 \%$ for the engine with Otto cycle to $41.5 \%$ for the engine with over-expanded cycle.

\section{ACKNOWLEDGMENT}

This project has received funding from the European Union's Horizon 2020 research and innovation program under grant agreement No 691232 - Knocky H2020-MSCA-RISE-2015/H2020-MSCA-RISE-2015 and the research was additionally co-financed by Polish Ministry of Science and Higher Education within the frame of science support funds for international co-funded projects in 2016-2019.

\section{REFERENCES}

1. White C. M., Steeper R. R., Lutz A. E. (2006) The Hydrogen-Fueled Internal Combustion Engine: a Technical Review. International Journal of Hydrogen Energy, 31 (10), 292-1305. https://doi.org/10.1016/j.ijhydene.2005.12.001.

2. Sierens R., Verhelst S. (2010) Experimental Study of a Hydrogen Fuelled Engine. Journal of Engineering for Gas Turbines and Power, 123 (1), 211-216. https://doi.org/10. 1115/1.1339989.

3. Heywood J. B. (1988) Internal Combustion Engine Fundamentals. McGraw-Hill Inc. 930.

4. Szwaja S., Bhandary K. R., Naber J. D. (2007) Comparison of Hydrogen and Gasoline Combustion Knock in a Spark Ignition Engine. International Journal of Hydrogen Energy, 32 (18), 5076-5087. https://doi.org/10.1016/j. ijhydene.2007.07.063.

5. Naber J. D., Szwaja S. (2007) Statistical Approach to Characterise Combustion Knock in the Hydrogen Fuelled SI Engine. Journal of Kones - Powertrain and Transport, 14 (3), 443-450.

6. Brunt M., Pond C., Biundo J. (1998) Gasoline Engine Knock Analysis Using Cylinder Pressure Data. SAE Technical Paper Series, 980896. https://doi.org/10.4271/980896.

7. Szwaja S., Naber J. D. (2008) Impact of Leaning Hydrogen-Air Mixtures on Engine Combustion Knock. Journal of Kones - Powertrain and Transport, 15 (2), 483-492.

8. Szwaja S., Naber J. D. (2007) Exhaust Gas Recirculation Strategy in the Hydrogen SI Engine. Journal of Kones Powertrain and Transport, 14 (2), 457-464.

9. Szwaja S., Naber J. D. (2013) Dual Nature of Hydrogen Combustion Knock. International Journal of Hydrogen Energy, 38 (28), 12489-12496. https://doi.org/10.1016/j. ijhydene.2013.07.036.

10. Szwaja S., Ansari E., Rao S., Szwaja M., Grab-Rogalinski K., Naber J. D., Pyrc M. (2018) Influence of Exhaust Residuals on Combustion Phases, Exhaust Toxic Emission and Fuel Consumption from a Natural Gas Fueled SparkIgnition Engine. Energy Conversion and Management, 165, 440-446. https://doi.org/10.1016/j.enconman. 2018.03.075.

11. Yang Z., Rao S., Wang Y., Harsulkar J., Ansari E., Narasimhamurthy N. M., Dice P., Naber J. D., Lonari Y., Szwaja S. (2018) Investigation of Combustion Knock Distribution in a Boosted Methane-Gasoline Blended Fueled SI Engine. SAE Technical Paper Series, 2018-01-0215. https://doi.org/10.4271/2018-01-0215.

12. Grab-Rogaliński K., Szwaja S. (2017) Combustion of the Biomethane in an IC Over-Expanded Engine. 2017 International Conference on Green Energy and Applications. https://doi.org/10.1109/icgea.2017.7925473.

13. Grab-Rogalinski K., Szwaja S. (2015) Influence of Intake Valve Closure Angle on IC Engine Indicated Parameters. Journal of Kones, 22 (3), 29-35.

14. Grab-Rogalinski K., Szwaja S. (2015) Miller Cycle Application to the Gaseous Supercharged SI Engine. Combustion Engines, R.44 3 (162), 881-885.

15. Grab-Rogaliński K., Szwaja S., Tutak W. (2014) The Miller Cycle Based IC Engine Fueled with a CNG/Hydrogen. Journal of Kones - Powertrain and Transport, 21 (4), 137-144. https://doi.org/10.1109/icgea.2017.7925473.

Received: 08.10.2019

Accepted: 10.12.2019

Published online: 30.07 .2020 